Akreditasi Ristekdikti,

No: 30/E/KPT/2019 (Sinta 4)

DOI: https://doi.org/10.31294/p.v23i2.11151

\title{
Prediksi Penjualan Produk Rokok Pada PT. Indomarco Prismatama Menggunakan Algoritma C4.5
}

\author{
Meliana Leonardi' ${ }^{1}$ Riska Emilda ${ }^{2}$, Irena Katrin ${ }^{3}$, Agus Yuliato ${ }^{4}$ \\ ${ }^{1}$ Universitas Nusa Mandiri \\ e-mail: melianaleonardi@gmail.com \\ ${ }^{2}$ Universitas Nusa Mandiri \\ e-mail: riskaemilda24@gmail.com \\ ${ }^{3}$ Universitas Nusa Mandiri \\ e-mail: irenakatrin18@gmail.com \\ ${ }^{4}$ Universitas Nusa Mandiri \\ e-mail: agus.aag@nusamandiri.ac.id
}

\begin{abstract}
Abstrak - Pandemi Covid-19 setidaknya membawa pengaruh buruk pada ekonomi nasional sepanjang tahun 2020 yang dampaknya dapat dirasakan tak terkecuali oleh retail. Tujuan dari penelitian ini adalah untuk menginformasikan prediksi penjualan produk rokok pada Indomaret Plus Eco RSUD Cengkareng agar perusahaan dapat melakukan pengadaan barang sesuai dengan permintaan. Adanya prediksi yang tepat diharapkan dapat mengatasi beberapa masalah dalam penjualan produk rokok pada Indomaret Plus Eco RSUD Cengkareng seperti menumpuknya dan ketidakteraturan produk membuat toko harus terus melakukan FEFO (First Expired First Out) yang dalam praktiknya cukup memakan waktu ataupun overproduction dan under production. Metode yang digunakan dalam penelitian ini adalah algoritma C4.5. Algoritma C4.5 merupakan algoritma klasifikasi data dengan tipe pohon keputusan. Nilai akurasi tertinggi diperoleh dari pengujian dengan 58 data training dan 37 data testing, menunjukkan tingkat akurasi $92,11 \%$, tingkat kesalahan 7,894\% dan nilai AUC 87,8\% dengan akurasi klasifikasi baik. Ukuran merupakan atribut yang paling mempengaruhi penjualan produk tembakau, tergolong bestseller atau underseller.
\end{abstract}

Kata Kunci: Data Mining, Decision Tree, Prediksi Penjualan.

Abstract - The Covid-19 pandemic has had a bad influence on the national economy throughout 2020, the impact of which can be felt, including by retail. The purpose of this study is to inform the prediction of sales of cigarette products at Indomaret Plus Eco RSUD Cengkareng so that companies can procure goods according to demand. The correct prediction is expected to overcome several problems in selling cigarette products at Indomaret Plus Eco RSUD Cengkareng, such as piling up and product irregularities, making the store have to continue to carry out FEFO (First Expired First Out) which in practice is quite a time consuming or overproduction and under production. The method in this research is the C4.5 Algorithm. The C4.5 algorithm is a data classification algorithm with the type of decision tree (decision tree). The highest accuracy value was obtained from experiments with 58 training data and 37 testing data, which showed an accuracy rate of $92.11 \%$, an error rate of $7.894 \%$, and an AUC value of $87.8 \%$ with good classification accuracy. Size is the attribute that most influences the sale of cigarette products, which are classified as selling or not selling well.

Keywords: Data Mining, Decision Tree, Sales Prediction.

\section{PENDAHULUAN}

Perekonomian industri di Indonesia terus berkembang yang menyebabkan persaingan yang ketat di seluruh sektor industri, khususnya pada industri rokok. Salah satu peran penting bagi perusahaan untuk menentukan strategi penjualan adalah prediksi penjualan. Info berupa pola mampu digunakan sebagai suatu solusi untuk pengambilan keputusan pada dunia perbisnisan serta jua untuk

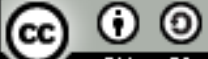


suatu pengembangan bisnis lainnya (Thabit, Alhomdy, Al-Ahdal, \& Jagtap, 2020). Informasi yang ada dapat digunakan sebagai tolak ukur membuat prediksi penjualan Selain itu, hasil prediksi penjualan dapat memberikan gambaran mengenai persediaan bahan baku yang dibutuhkan perusahaan dalam menjalankan kegiatan produksi. Gambaran yang tepat dapat mencegah kerugian perusahaan akibat overproduction maupun under production pada biaya penyimpanan.

Perusahaan PT. Indomarco Prismatama pada Indomaret RSUD Cengkareng merupakan toko pada perusahaan retail yang menjual berbagai jenis rokok dari berbagai supplier. Supplier yang telah bekerja sama dengan PT. Indomarco Prismatama antara lain : PT. Surya Mustika Nusantara, PT. Niaga Nusa Abadi, PT. Korea Tomorrow dan Global Indonesia, PT. Sumber Cipta Multiniaga, PT. Gudang Garam, PT. Gelora Djaja, PT. Bentoel Distribusi Utama, dan PT. HM Sampurna. Akumulasi dari beberapa supplier yang bekerjasama mengadakan 3 jenis kategori rokok yaitu SKT (Sigaret Kretek Tangan), SKM (Sigaret Kretek Mesin), dan SPM (Sigaret Putih Mesin). Pada toko Indomaret RSUD Cengkareng dalam kurun waktu dua bulan yang lalu terhitung dari tanggal 22 April 2021 mampu menjual 2.990 bungkus yang mana PKM (Permintaan Kuantiti Maksimum) yaitu sebanyak 3.281 bungkus.

Pada bulan Maret - April tahun 2021, PT. Indomarco Prismatama melakukan penarikan bea cukai rokok tahun 2020 dari semua mitra supplier. Tercatat terdapat penarikan sebanyak 163 bungkus pada toko Indomaret Plus Eco RSUD Cengkareng. Permasalahan terjadi akibat dari tidak berjalannya FEFO (First Expired First Out) dari DC (Distribution Center) ataupun bersumber dari toko karena produk yang tidak teratur. Dampak lanjut dari permasalahan ini yaitu menumpuknya persediaan rokok produksi lama dan produk rokok yang tidak sesuai dengan minat pembeli yang berakibat terjadi penarikan pada saat pergantian bea cukai pertahun. Terlebih jika ada penumpukan persediaan barang yang berpotensi menambah kerugian pelaku usaha akibat pandemi Covid-19(Pusat Data dan Analisa Tempo, 2021).

Berdasarkan uraian di atas, dibutuhkan metode yang bisa membantu prediksi produk yang laku dan kurang laku sesuai dengan minat pembeli di pasaran sehingga toko Indomaret RSUD Cengkareng menentukan jumlah PKM (Permintaan Kuantiti Maksimal) rokok pada periode selanjutnya. Ada suatu tahapan atau langkah untuk menemukan pattern atau pola informasi pada sekumpulan data dengan memakai algoritma tertentu di pada data mining. algoritma yang akan digunakan pada perkara ini merupakan algoritma C4.5. Algoritma C4.5 yaitu suatu algoritma yang bisa dipergunakan untuk membentuk pohon keputusan. Kelebihan berasal algoritma C4.5 diantaranya dapat menghasilkan pohon keputusan yang dipresentasikan dengan mudah, mempunyai tingkat akurasi yang bisa diterima, efisien pada menangani atribut bertipe diskret serta numeric (Muhammad Rizal, 2019).

Penelitian terkait menggunakan algoritma $\mathrm{C} 4.5$ untuk dengan ruang lingkup lain yaitu jurnal berjudul Penerapan Algoritma C4.5 Untuk Penentuan Ketersediaan Barang E-Commers untuk menklasifikasikan stok barang yang harus ditambah dan yang tidak. Hasil akurasi yang didapatkan dari analisis menggunakan pohon keputusan dalam penelitian ini sebesar $98.9 \%$ dari 5.000 sampel data dan 23 atribut (Lukhayu Pritalia, 2018). Selain itu, penelitian terkait lainnya adalah jurnal berjudul Analisa Algoritma C4.5 Untuk Memprediksi Penjualan Motor Pada PT. Capela Dinamik Nusantara Cabang Muka Kuning. Pada penelitian ini menghasilkan nilai gain tertinggi yaitu 0.6965 dan menghasilkan suatu pohon keputusan guna melihat pola prediksi perilaku konsumen pembeli motor (Azwanti, 2018)

Pada penelitian ini penulis akan menerapkan salah satu algoritma decision tree yaitu algoritma C4.5 untuk membentuk pohon keputusan. Algoritma C4.5 ialah suatu algoritma yang termasuk ke dalam fungsi pengelompokan data yang menghasilkan suatu pohon keputusan (decision tree) dihasilkan dari perhitungan entropy serta gain ratio guna pengolahan atribut menjadi node (Izzulhaq \& Sulastri, 2020). Pada algoritma C4.5 Jumlah data berbanding lurus dengan tingkat keakuratan, sehingga semakin banyak data maka tingkat keakuratan akan semakin tinggi (Lukhayu Pritalia, 2018). metode algoritma C4.5 bertujuan untuk membangun pohon keputusan diantaranya (Eska, 2018):

a. Tentukan atribut yang nantinya akan berperan sebagai akar pohon

b. Kemudian, setiap nilai dibentuk sebuah cabang.

c. Bagi kasus pada sebuah cabang

d. Ulangi proses pada tiap cabang hingga mempunyai kelas yang sama.

Dari penelitian terkait menunjukan penggunaan algoritma C4.5 untuk memprediksi penjualan memperoleh nilai akurasi yang baik diharapkan dengan penggunaan algoritma $\mathrm{C} 4.5$ bisa mencari tahu bahwa kinerja juga tingkat akurasi terbaik dari dataset dalam penelitian ini. 


\section{METODOLOGI PENELITIAN}

Penelitian ini menggunakan metode Knowledge Discovery in Database (KDD). Metode yang digunakan untuk mendapatkan pengetahuan asal dari sebuah database merupakan definisi dari KDD. Proses kerja KDD terlihat pada gambar di bawah ini: Sumber: (Nikmatun \& Waspada, 2019)

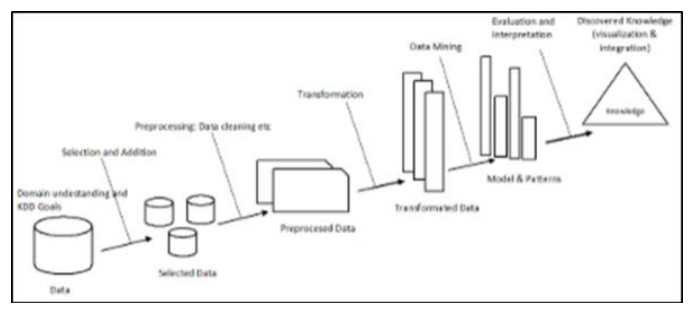

Gambar 1. Proses Knowledge Discovery in Database

Data Selection (Data Seleksi)

Tahapan ini merupakan tahapan dimana data-data dikumpulkan dan kemudian diolah dengan metode Decision Tree algoritma C4.5. Berikut ini adalah data penjualan rokok pada Indomaret Plus Eco RSUD Cengkareng yang akan digunakan untuk pemrosesan data yang diolah dengan metode decison tree. Jumlah dataset asli pada data produk rokok sebanyak 95 record. Dari semua atribut yang ada terdapat 6 atribut yang akan digunakan dalam proses KDD. Atribut tersebut yaitu:

Tabel 1. Pemilihan Atribut

\begin{tabular}{cll}
\hline Atribut & & Detail Penggunaan \\
\hline Id Produk & $\backslash$ & Tidak \\
Nama & $\checkmark$ & ID \\
Produk & & \\
Jenis & $\checkmark$ & Nilai Model \\
Kategori & $\checkmark$ & Nilai Model \\
Produk & & \\
Ukuran & $\checkmark$ & Nilai Model \\
Minat & $\checkmark$ & Nilai Model \\
\hline Sumber: (Leonardi, Emilda, \& Katrin, 2021)
\end{tabular}

Sumber: (Leonardi, Emilda, \& Katrin, 2021)

Tabel di atas menjelaskan atribut-atribut yang akan digunakan dalam survei, indicator ya $(\checkmark)$ berarti atribut-atribut tersebut akan digunakan dalam survei. Meskipun indikator tidak $(X)$ menunjukkan bahwa atribut tersebut tidak digunakan dalam tahap data mining investigasi.

\section{Processing (Cleaning)}

Setelah dilakukan data selection, atribut atau variabel yang digunakan terdiri dari 5 atribut yang terdapat dalam penentuan minat. Dengan 3 atribut predictor, 1 atribut ID dan 1 atribut target. Pada atribut jenis, kategori produk, dan ukuran memiliki value yang dapat dilihat pada tabel dibawah ini:

Tabel 2. Atribut dan Value

\begin{tabular}{cl}
\hline Atribut & Value \\
\hline Jenis & Filter \\
& Kretek \\
& Mild \\
Kategori Produk & SKT \\
& SKM \\
& SPM \\
Ukuran & Besar \\
& Sedang \\
& kecil
\end{tabular}

Sumber: (Leonardi et al., 2021)

\section{Data Transformation}

Dalam tahap data transformation tidak ada data yang dibersihkan, pembagian data set dengan menggunakan process split data untuk mnghasilkan data training dan data testing dengan rasio 60:40. Data training berjumlah 58 data dan data testing 37 data dari total keseluruhan yaitu 95 data. Tabel data tersebut dapat dilihat pada gambar berikut:

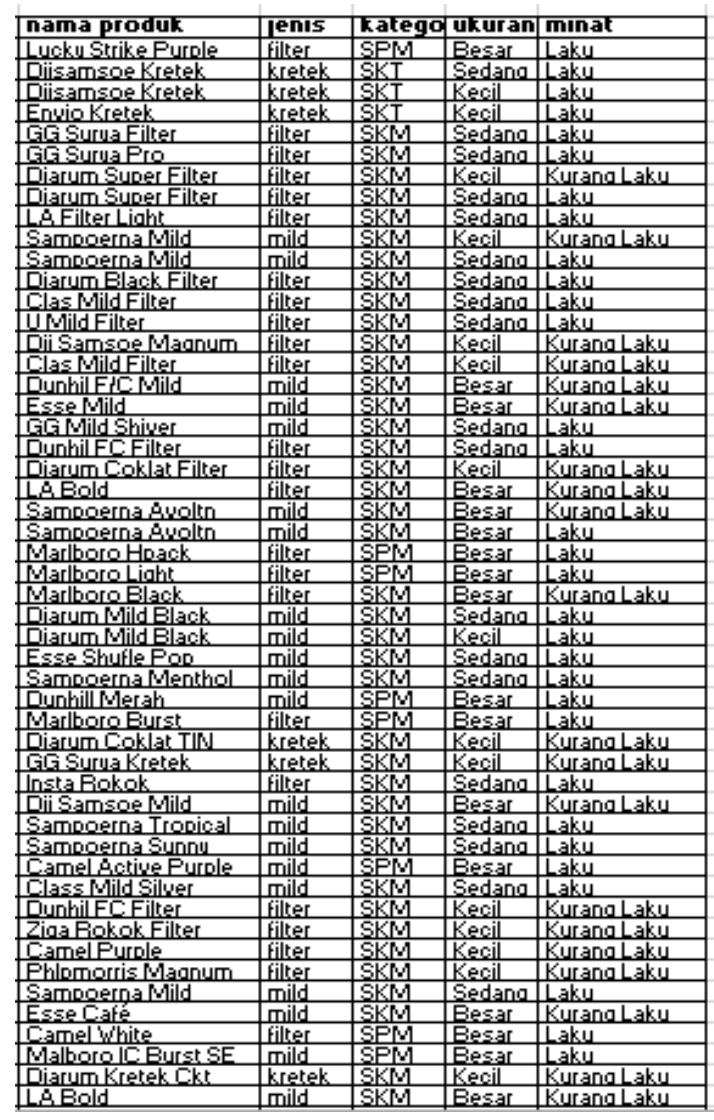

Sumber: (Leonardi et al., 2021)

Gambar 2. Data Training 


\begin{tabular}{|c|c|c|c|c|}
\hline nama produk & jenis & kategori pr & ukuran & minat \\
\hline Diarum Kretek & kretek & SKT & Kecil & Laku \\
\hline 234 Rokok & kretek & SKT & Kecil & Laku \\
\hline Sampoerna Kretek & kretek & SKT & Kecil & Laku \\
\hline Marlborolce Brust & filter & SPM & Besar & Laku \\
\hline Sampoerna Hijau & kretek & SKT & Kecil & Laku \\
\hline GG Filter Merah & filter & SKM & Kecil & Kurang La \\
\hline Wismilak Diplomat & kretek & SKM & Kecil & KurangLa \\
\hline LA Light Menthol & mild & SKM & Sedang & Laku \\
\hline GG Surya Pro Mild & mild & SKM & Sedang & Laku \\
\hline Envio Mild & mild & SKM & Sedang & Kurang La \\
\hline Diarum Super Mild & mild & SKM & Sedang & Kurang Lak \\
\hline GG Surya & kretek & SKM & Sedang & Laku \\
\hline Diarum Super Mild & mild & SKM & Besar & KurangLa \\
\hline GG Signature & Filter & SKM & Kecil & Laku \\
\hline LAlce & mild & SKM & Sedang & Laku \\
\hline Esse Chng Aplmnt & mild & SKM & Besar & Kurang \\
\hline LABold & filter & SKM & Kecil & \\
\hline Dii Samsoe & kretek & SKM & Sedang & Laku \\
\hline Lucky Strike Filter & filter & SPM & Besar & Laku \\
\hline GG Surya Filter & filter & SKM & Kecil & Kurang \\
\hline Esse Change GRP & mild & SKM & Besar & Kuran \\
\hline LABold & filter & SKM & Sedang & Laku \\
\hline Esse Change Juicy & mild & SKM & Besar & Kurang Lak \\
\hline Esse Change Doub & mild & SKM & Sedang & Laku \\
\hline Diplomat Evo & kretek & SKM & Sedang & Laku \\
\hline Diarum Wave & mild & SKM & Kecil & Laku \\
\hline Marlboro Hpack & Filter & SPM & Besar & Laku \\
\hline Malboro Advance & filter & SKM & Kecil & Kurang Lak \\
\hline Esse Punch Pop & mild & SKM & Sedang & Laku \\
\hline Forte Driginal & kretek & SPM & Besar & Laku \\
\hline Forte Menthol & kretek & SPM & Besar & Laku \\
\hline Esse Berry Pop & mild & SPM & Sedang & Laku \\
\hline Diisamsoe EDS & kretek & SKT & Kecil & Laku \\
\hline DG Kretek Spack & kretek & SKT & Kecil & Laku \\
\hline Win Bold & Mild & SKM & Besar & KurangLakı \\
\hline Esse Golden leaf & filter & SPM & Besar & Laku \\
\hline Forte Brz Mntl & kretek & SPM & Besar & Laku \\
\hline Esse Filter Blue & \begin{tabular}{|l|l|} 
mild \\
\end{tabular} & SPM & Besar & Laku \\
\hline
\end{tabular}

Sumber: (Leonardi et al., 2021)

Gambar 3. Data Testing

\section{Data Mining}

Metode yang penulis gunakan dalam mencari pola menarik adalah metode Decision Tree, Algoritma C4.5 yang merupakan salah satu algoritma dalam fungsi klasifikasi. Algoritma C4.5 memberikan hasil akhir berupa pohon keputusan (decision tree) dari hasil perhitungan entropy dan gain ratio untuk pengolahan atribut menjadi node.

\section{Interpretation / Evalaution}

Pada tahap evaluasi melibatkan hasil perhitungan accuracy, precision, error rate dan recall dari data testing dengan bantuan Confusion Matrix. Sedangkan, dalam tahap interpretasi merupakan visualisasi dari hasil evaluasi yang sudah dilakukan.

\section{HASIL DAN PEMBAHASAN}

Pada penelitian ini dilakukan perhitungan secara manual dan dengan bantuan tools RapidMiner untuk mendapatkan sebuah pohon keputusan (decision tree) yang dapat memprediksi penjualan produk rokok pada PT Indomarco Prismatama Cabang Indomaret Plus Eco RSUD Cengkareng.
1. Perhitungan Secara Manual

Sesuai dengan langkah pembuatan pohon keputusan (decision tree) setelah melakukan analisis data yang menghasilkan data training dan data testing maka dilanjutkan dengan menentukan nilai entropy dan gain pada data training. Hasil perhitungan akan digunakan untuk menentukan root atribut atau atribut yang akan menjadi the best classifier.

Rumus menghitung nilai entropy:

$$
\begin{aligned}
& \text { Entropy }(\mathrm{S})=\sum_{i=1}^{n}-p i * \log 2 p i \\
& \qquad \begin{array}{l}
\text { Keterangan }: \\
\mathrm{S}=\text { himpunan kasus } \\
\mathrm{n}=\text { jumlah partisi } \mathrm{S} \\
\mathrm{pi}=\text { proporsi } \mathrm{Si} \text { terhadap } \mathrm{S}
\end{array}
\end{aligned}
$$

Menhitung nilai gain menggunakan rumus:

$$
\begin{aligned}
& \operatorname{Gain}(\mathrm{S}, \mathrm{A})=\operatorname{Entropy}(\mathrm{S})-\sum_{i=1}^{n} \frac{\left|S_{i}\right|}{S} * \operatorname{Entropy}(S) \\
& \text { Keterangan : } \\
& \mathrm{S}=\text { Himpunan Kasus } \\
& \mathrm{A}=\text { Atribut } \\
& \mathrm{n}=\text { Jumlah Partisi Atribut A } \\
& |\mathrm{Si}|=\text { Jumlah Kasus pada partisi ke-i } \\
& |\mathrm{S}|=\text { Jumlah Kasus dalam } \mathrm{S}
\end{aligned}
$$

Didapatkan hasil perhitungan seperti pada gambar di bawah ini:

\begin{tabular}{|l|c|c|c|c|r|c|}
\hline atribut & value & $\begin{array}{c}\text { jumlah } \\
\text { kasus } \\
(\mathrm{s})\end{array}$ & $\begin{array}{c}\text { laku } \\
\left(\mathrm{S}_{1}\right)\end{array}$ & $\begin{array}{c}\text { kurang } \\
\text { laku }\end{array}$ & entropy & gain \\
\hline total & & 57 & 36 & 21 & 0.949452015 & \\
\hline & & & & & & 0.195360384 \\
\hline $\begin{array}{l}\text { Kategori } \\
\text { Produk }\end{array}$ & & & & & 0 & \\
\hline & SKT & 3 & 3 & 0 & 0 & \\
\hline & SKM & 43 & 22 & 21 & 0.999609836 & \\
\hline & SPM & 11 & 11 & 0 & 0 & \\
\hline & & & & & 0.374010544 \\
\hline Ukuran & & & & & 0 & \\
\hline & Kecil & 17 & 4 & 13 & 0.787126586 & \\
\hline & Sedang & 20 & 20 & 0 & 0 & \\
\hline & Besar & 20 & 12 & 8 & 0.970950594 & \\
\hline & & & & & & \\
\hline Jenis & & & & & 1 & 0.011631625 \\
\hline & Kretek & 6 & 3 & 3 & & \\
\hline & Filter & 28 & 17 & 11 & 0.966618633 & \\
\hline & Mild & 23 & 16 & 7 & 0.886540893 & \\
\hline
\end{tabular}

Sumber: (Leonardi et al., 2021)

Gambar 4. Hasil Perhitungan Entropy dan Gain 


\begin{tabular}{|l|c|c|c|c|c|c|}
\hline Atribut & Value & $\begin{array}{c}\text { jumlah } \\
\text { kasus } \\
(\mathrm{s})\end{array}$ & $\begin{array}{c}\text { laku } \\
\left(\mathrm{S}_{1}\right)\end{array}$ & $\begin{array}{c}\text { kurang } \\
\text { laku }\end{array}$ & entropy & gain \\
\hline & & & & & & \\
\hline Ukuran & & & & & & \\
\hline & $\begin{array}{c}\text { Kecil } \\
\& \\
\text { Besar }\end{array}$ & 37 & 16 & 21 & 0.98678672 & \\
\hline & & & & & & \\
\hline $\begin{array}{l}\text { Kategori } \\
\text { Produk }\end{array}$ & & & & & & 0.634204379 \\
\hline & SKT & 2 & 2 & 0 & 0 & \\
\hline & SKM & 24 & 3 & 21 & 0.543564443 & \\
\hline & SPM & 11 & 11 & 0 & 0 & \\
\hline & & & & & & \\
\hline Jenis & & & & & & 0.008187511 \\
\hline & Kretek & 5 & 2 & 3 & 0.970950594 & \\
\hline & Filter & 18 & 7 & 11 & 0.964078765 & \\
\hline & Mild & 14 & 7 & 7 & & \\
\hline
\end{tabular}

Sumber: (Leonardi et al., 2021)

Gambar 5. Lanjutan Hasil Perhitungan Entropy dan Gain

\begin{tabular}{|l|c|c|c|c|c|c|}
\hline atribut & value & $\begin{array}{c}\text { jumlah } \\
\text { kasus } \\
(\mathrm{s})\end{array}$ & $\begin{array}{c}\text { laku } \\
\left(\mathrm{S}_{1}\right)\end{array}$ & $\begin{array}{c}\text { kurang } \\
\text { laku }\end{array}$ & entropy & gain \\
\hline $\begin{array}{l}\text { Kategori } \\
\text { Produk }\end{array}$ & & & & & & \\
\hline & SKM & 24 & 3 & 21 & 0.543564443 & \\
\hline & & & & & & \\
\hline Jenis & & & & & & 0.910768985 \\
\hline & Kretek & 3 & 0 & 3 & 0 & \\
\hline & Filter & 11 & 0 & 11 & 0 & \\
\hline & Mild & 10 & 3 & 7 & 0.881290899 & \\
\hline
\end{tabular}

Sumber: (Leonardi et al., 2021)

Gambar 6. Lanjutan Hasil Perhitungan Entropy dan Gain

Didapatkan pohon keputusan secara manual sebagai berikut.

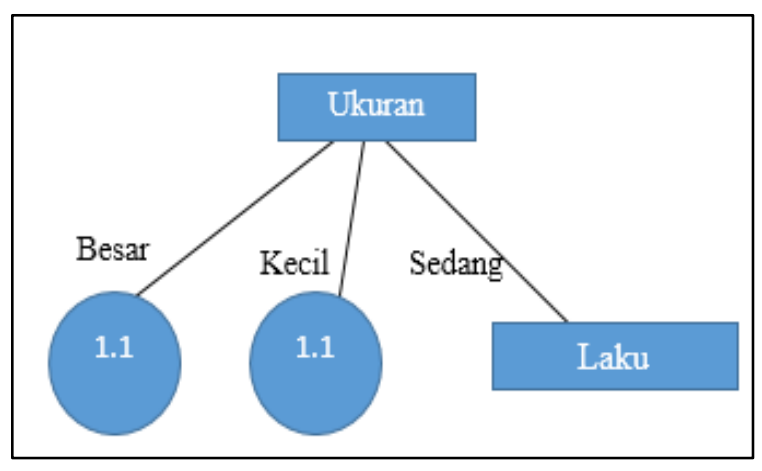

Sumber: (Leonardi et al., 2021)

Gambar 7. Pohon Hasil Perhitungan Menentukan Root

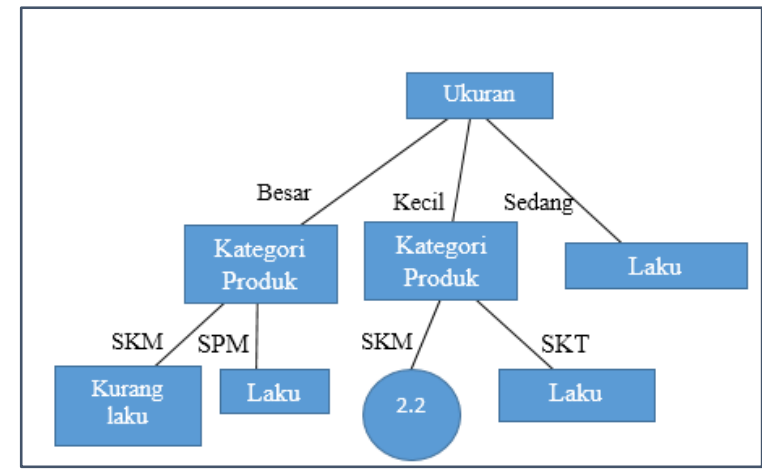

Sumber: (Leonardi et al., 2021)

Gambar 8. Pohon Hasil Perhitungan Menentukan Subtree Pertama

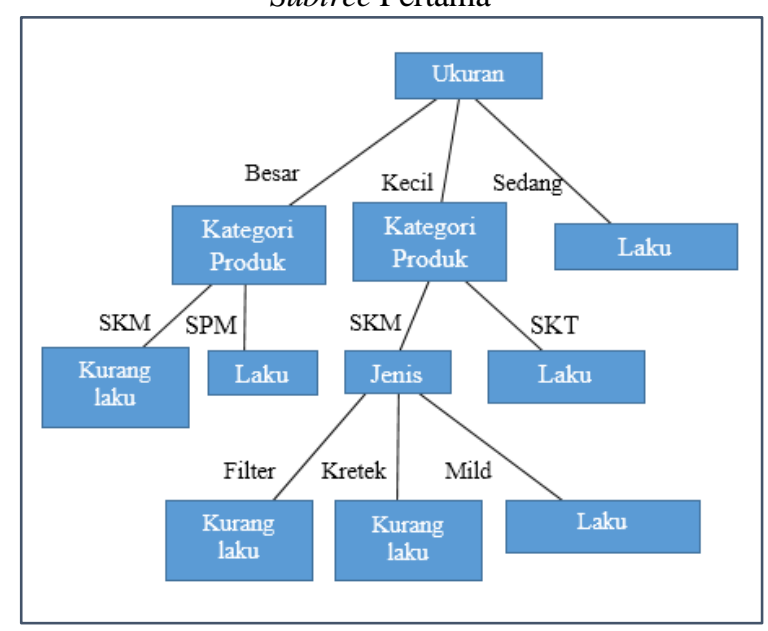

Gambar 9. Pohon Hasil Perhitungan Menentukan Subtree Kedua

2. Evaluasi Hasil Manual

Setelah selesai menghitung entropy dan gain, selanjutnya yang akan dilakukan adalah menghitung accuracy, precision, recall dan error rate pada data dengan bantuan confusion matrix. Confusion matrix memiliki empat istilah hasil proses klasifikasi, yaitu True Positive (TP), True Negative (TN), False Positive (FP), False Negative (FN).

\begin{tabular}{|c|c|c|}
\hline \multirow{2}{*}{ Actual } & \multicolumn{2}{|c|}{ Predicted } \\
\cline { 2 - 3 } & - & + \\
\hline- & 10 & 2 \\
\hline+ & 1 & 25 \\
\hline
\end{tabular}

Sumber: (Leonardi et al., 2021)

\section{Gambar 10. Hasil Confusion Matrix}

a. Accuracy

Accuracy dapat dihitung menggunakan rumus: 
Accuracy $=\frac{T N+T P}{T N+T P+F N+F P} \times 100 \%$

b. Error Rate

Nilai error rate dapat dihitung dengan menggunakan rumus:

Error Rate $=\frac{F P+F N}{T N+T P+F N+F P} \times 100 \%$

c. Precision

Precision dapat dihitung menggunakan rumus:

Precision $=\frac{T P}{F P+T P} \times 100 \%$

d. Recall

Nilai recall dapat dihitung dengan menggunakan rumus:

Recall $=\frac{T P}{F N+T P} \times 100 \%$

e. Spesificity

Nilai spesificity dapat dihitung dengan menggunakan rumus:

Spesificity $=\frac{T N}{T N+F P} \times 100 \%$

Didapatkan hasil perhitungan seperti pada gambar di bawah ini.

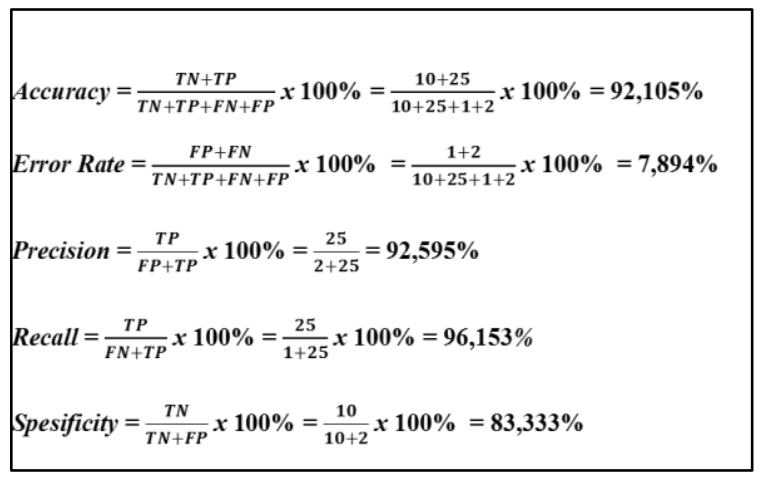

Sumber: (Leonardi et al., 2021)

Gambar 11. Hasil Perhitungan Evaluasi

3. Perhitungan Menggunakan RapidMiner

Dengan menggunakan algoritma C4.5, akan dibentuk pohon keputusan (decision tree) menggunakan bantuan tools RapidMiner. Langkah pertama adalah import data

\begin{tabular}{|c|c|c|c|c|c|c|c|c|}
\hline \multicolumn{9}{|c|}{ Import Dala - Select the cells to import. } \\
\hline \multicolumn{9}{|c|}{ Select the cells to import. } \\
\hline \multicolumn{2}{|c|}{ Sheet: sneet1 $v$} & \multicolumn{2}{|c|}{ Cell range: $\mathrm{Cl}: \mathrm{:58}$} & \multirow{2}{*}{$\begin{array}{l}\text { Select All } \\
\text { D }\end{array}$} & \multicolumn{3}{|c|}{$\checkmark$ Denne header r row: $\quad 1 \div$} & \\
\hline & A & в & c & & E & $\mathrm{F}$ & & G \\
\hline 1 & No. & id produk & nama produk & jenis & kategori prod. & ukuran & & minat \\
\hline 2 & 1000 & 20102468.000 & Lucky Strike $P$. & filer & SPM & Besar & & Laku \\
\hline 3 & 5.000 & 10025255.000 & Disamsoe Kt... & kretek & sкT & Sedang & & Laku \\
\hline 4 & 6.000 & 10030733.000 & Disamsoe Kt... & kretek & sкт & Kecil & & Laku \\
\hline 5 & 7.000 & 20101033.000 & Envio Kretek & ketek & sкT & Kecil & & Laku \\
\hline 6 & 10.000 & 10010075.000 & GQ Surya Fitter & filier & sкM & Sedang & & Laku \\
\hline 7 & 11.000 & 10010077.000 & GG Surya Pro & filer & skM & Sedang & & Laku \\
\hline 8 & 13.000 & 10010081.000 & Diarum Super.... & filier & SKM & Kecil & & Kurang Laku \\
\hline 9 & 14.000 & 10010082.000 & Djarum Super... & filer & SKM & Sedang & & Laku \\
\hline 10 & 15.000 & 10010084.000 & LA Filter LIgnt & niter & skm & sedang & & Laku \\
\hline 11 & 16.000 & 10010090.000 & Sampoerna Mi... & mild & sкм & Kecil & & Kurang Laku \\
\hline 12 & 17.000 & 10010091.000 & Sampoerna Mi... & mild & sкM & Sedang & & Laku \\
\hline 13 & 20.000 & 10014528.000 & Djarum Black... & filter & SKM & Sedang & & Laku \\
\hline 14 & 21.000 & 10024523.000 & Clas Nild Fitter & filier & SKM & Sedano & & Laku \\
\hline \multirow[t]{2}{*}{15} & $m \mathrm{nnn}$ & 2ถกก 178 ก กก & Unistritar & filtar & скм & cordonn & & I skn \\
\hline & & & & & & Erevious & $\rightarrow$ Neet & $\mathbf{X}_{\text {cancel }}$ \\
\hline
\end{tabular}

Sumber: (Leonardi et al., 2021)

Gambar 12. Import Data

Dilanjutkan dengan menambahakan operators yang dibutuhkan.

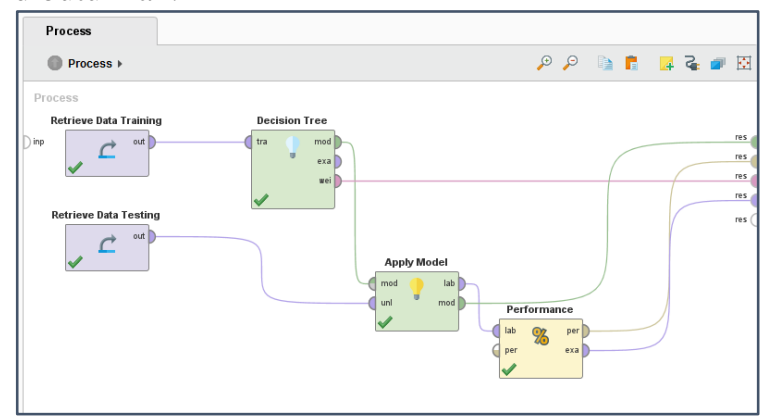

Sumber: (Leonardi et al., 2021)

Gambar 13. Menambahkan Operators

Lakukan running procces untuk mendapatkan hasil berupa pohon keputusan dari data training atau training samples dan mendapatkan keakuratan dari data testing atau testing samples. Berikut adalah pohon keputusan yang didapatkan dengan bantuan tools RapidMiner.

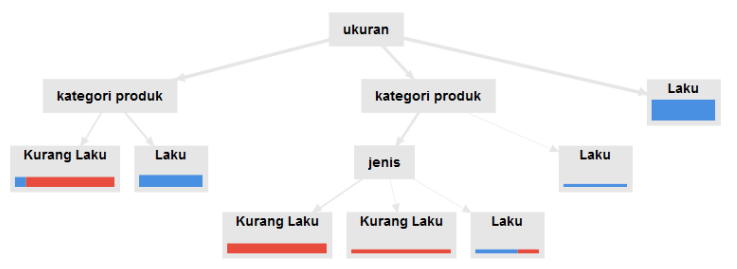

Sumber: (Leonardi et al., 2021)

Gambar 14. Pohon Keputusan

Rule yang dihasilkan adalah sebagai berikut. 


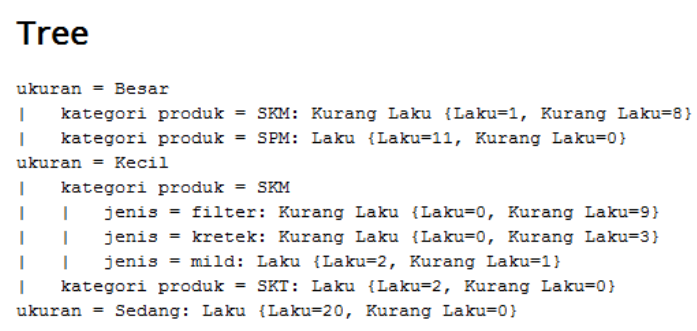

Sumber: (Leonardi et al., 2021)

Gambar 15. Rule Pohon Keputusan

1.Jika produk berukuran Besar dengan kategori SKM, maka produk tersebut Kurang Laku. Perbandingan Laku dan Kurang Laku adalah 1:8. 2.Jika produk berukuran Besar dengan kategori SPM, maka produk tersebut Laku. Perbandingan Laku dan Kurang Laku adalah 11:0.

3.Untuk produk berkuran Kecil dengan kategori SKM dan berjenis filter maka produk Kurang Laku. Perbandingan Laku dan Kurang Laku adalah 0:9.

4.Untuk produk berkuran Kecil dengan kategori SKM dan berjenis kretek maka produk Kurang Laku. Perbandingan Laku dan Kurang Laku adalah $0: 3$.

5.Untuk produk berkuran Kecil dengan kategori SKM dan berjenis mild maka produk Laku. Perbandingan Laku dan Kurang Laku adalah 2:1. 6.Jika produk berkuran Kecil dan berkategori SKT maka produk tersebut Laku dengan perbandingan jumlah Laku dan Kurang Laku 2:0.

7.Untuk produk berukuran sedang mendapat jumlah Laku sebanyak 20 dan Kurang Laku 0 sehingga dapat disimpulkan produk berukuran sedang, Laku.

Dari rule di atas didapatkan prediksi produk rokok Laku adalah seperti gambar di bawah ini.

\begin{tabular}{|c|c|c|c|}
\hline No. & Rules Laku & $\begin{array}{l}\text { Jumlah Produk } \\
\text { Laku }\end{array}$ & Nama Produk \\
\hline & $\begin{array}{l}\text { Ukuran: Besar } \\
\text { Kategori: SPM }\end{array}$ & 11 & $\begin{array}{l}\text { 1. Lucky Strike Purple Boster } \\
\text { 2. Marlboro Hpack } \\
\text { 3. Marlboro Light } \\
\text { 4. Dumhill Merah } \\
\text { 5. Marlboro Burst } \\
\text { 6. Camel Active Purple Mint } \\
\text { 7. Camel White } \\
\text { 8. Malboro IC Burst SE } \\
\text { 9. Dumhill Biru Light } \\
\text { 10. Dumhill Hijau Menthol } \\
\text { 11. Esse Blue Change }\end{array}$ \\
\hline 2 & $\begin{array}{l}\text { Ukuran: Kecil } \\
\text { Kategori: SKM } \\
\text { Jenis: Mild }\end{array}$ & 2 & $\begin{array}{l}\text { 1. Sampoerna Mild } \\
\text { 2. GG Signt Mild }\end{array}$ \\
\hline 3 & $\begin{array}{l}\text { Ukuran: Kecil } \\
\text { Kategori: SKT }\end{array}$ & 2 & $\begin{array}{l}\text { 1. Djisamsoe Kretek } \\
\text { 2. Envio Kretek }\end{array}$ \\
\hline 4. & Ukuran: Sedang & 20 & $\begin{array}{l}\text { 1. Djisamsoe Kretek } \\
\text { 2. GG Surya Filter } \\
\text { 3. GG Surya Pro } \\
\text { 4. Djarum Super Filter } \\
\text { 5. LA Filter Light } \\
\text { 6. Sampoerna Mild } \\
\text { 7. Djarum Black Filter } \\
\text { 8. Clas Mild Filter } \\
\text { 9. U Mild Filter } \\
\text { 10. GG Mild Shiver } \\
\text { 11. Dunhil FC Filter } \\
\text { 12. Djarum Mild Black } \\
\text { 13. Esse Shufle Pop } \\
\text { 14. Sampoerna Menthol } \\
\text { 15. Insta Rokok } \\
\text { 16. Sampoerna Tropical } \\
\text { 17. Sampoerna Sunny } \\
\text { 18. Class Mild Silver } \\
\text { 19. Sampoerna Mild } \\
\text { 20. Malboro Black. }\end{array}$ \\
\hline
\end{tabular}

Sumber: (Leonardi et al., 2021)

Gambar 16. Prediksi Produk Rokok Laku

4.Hasil Performance Testing Samples pada RapidMiner

Performance meliputi hasil perhitungan accuracy dan ROC/AUC.

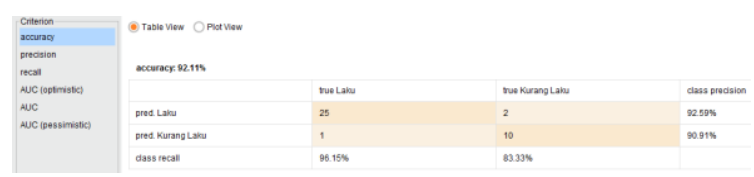

Sumber: (Leonardi et al., 2021)

Gambar 17. Accuracy Data Testing pada RapidMiner

Performance keakurasian AUC (Gorunescu, 2010) dapat diklasifikasikan menjadi lima kelompok yaitu(Tusarwenda, 2018):
a. $\quad 0.90-1.00=$ Excellent Classification .
b. $\quad 0.80-0.90=$ Good Classification
c. $\quad 0.70-0.80=$ Fair Classification .
d. $\quad 0.60-0.70=$ Poor Classification
e. $\quad 0.50-0.60=$ Failure . 


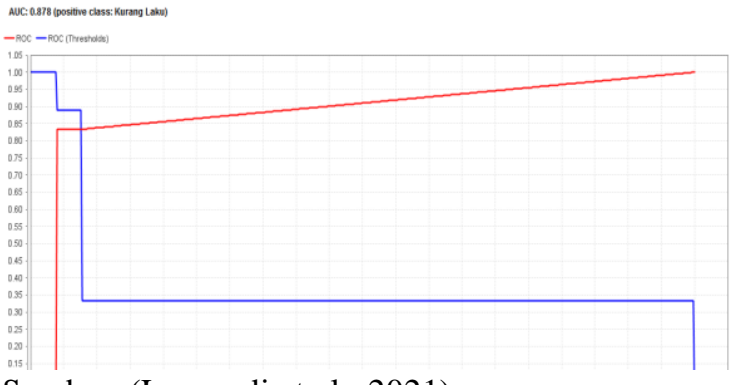

Sumber: (Leonardi et al., 2021)

Gambar 18. AUC Data Testing pada RapidMiner

Dari gambar di atas dapat dilihat hasil dari pengolahan AUC data testing menggunakan Algoritma C4.5 sebesar 0,878 dengan tingkat akurasi Good Classification.

\begin{tabular}{cl}
\hline & Cross Validation \\
\hline Accuracy & $92,11 \%$ \\
AUC & $0,878 \%$
\end{tabular}

Sumber: (Leonardi et al., 2021)

Dari tabel diatas untuk mengetahui prediksi penjualan pada toko Indomaret Plus Eco RSUD Cengkareng, menggunakan algoritma decision tree, model cross validation menghasilkan nilai $A U C$ $0,878 \%$ akurasi yang tinggi sebesar $92,11 \%$.

\section{Potensi Hasil}

Penelitian ini sendiri menggunakan salah satu algoritma pada metode Decision Tree yaitu Algoritma C4.5 untuk membuat pohon keputusan (Decision Tree) dan mendapatkan nilai accuracy sebesar $92.11 \%$ serta nilai AUC 0,878 atau 87,8\% dengan tingkat akurasi Good Classification. Sehingga dapat disimpulkan bahwa penggunaan metode Decision Tree dengan Algoritma C4.5 ini cukup tepat untuk menentukan prediksi penjualan rokok pada PT. Indomarco Prismatama Cabang Indomaret Plus Eco RSUD Cengkareng.

\section{KESIMPULAN}

Dari hasil perhitungan secara manual maupun dengan bantuan tools RapidMiner dari data training sebanyak 58 didapatkan pohon keputusan yang menciptakan rule untuk produk rokok yang termasuk ke dalam minat Laku adalah produk rokok dengan kondisi: berukuran Sedang; berukuran Kecil dan berkategori SKT; berukuran Besar dan berkategori SPM; berukuran Kecil, berkategori SKM dan bejenis mild. Berdasarkan evaluasi hasil menggunakan data testing sebanyak 37 data pada penelitian prediksi penjualan produk rokok menggunakan Algoritma C4.5 didapatkan nilai accuracy sebesar 92,11\% dan AUC 0,878 sehingga mendapatkan tingkat akurasi Good Classification.

\section{REFERENSI}

Azwanti, N. (2018). Analisa Algoritma C4.5 Untuk Memprediksi Penjualan Motor Pada Pt. Capella Dinamik Nusantara Cabang Muka Kuning. Informatika Mulawarman : Jurnal Ilmiah Ilmu Komputer, $13(1), \quad 33$. https://doi.org/10.30872/jim.v13i1.629

Eska, J. (2018). Penerapan Data Mining Untuk Prediksi Penjualan Wallpaper Menggunakan Algoritma C4.5. 2. https://doi.org/10.31227/osf.io/x6svc

Izzulhaq, A. F., \& Sulastri. (2020). Klasifikasi Penjualan Aplikasi Android. Proceeding SENDIU, 72(6), 978-979.

Leonardi, M., Emilda, R., \& Katrin, I. (2021). PREDIKSI PENJUALAN PRODUK ROKOK PADA PT. INDOMARCO PRISMATAMA CABANG INDOMARET PLUS ECO RSUD CENGKARENG MENGGUNAKAN ALGORITMA C4.5.

Lukhayu Pritalia, G. (2018). Penerapan Algoritma C4.5 untuk Penentuan Ketersediaan Barang Ecommerce. Indonesian Journal of Information Systems, $1(1), \quad 47-56$. https://doi.org/10.24002/ijis.v1i1.1727

Muhammad Rizal. (2019). Analisa Prediksi Penjualan Produk Dengan Menggunakan Metode C4.5 (Studi Kasus : PT. Kawan Lama Ace Hardware). Jurnal Riset Komputer, 6(5), 545-549. Retrieved from https://ejurnal.stmikbudidarma.ac.id/index.php/jurikom/article/vie w/1656/1253

Nikmatun, I. A., \& Waspada, I. (2019). Implementasi Data Mining untuk Klasifikasi Masa Studi Mahasiswa Menggunakan Algoritma KNearest Neighbor. Jurnal SIMETRIS, 10(2), 421-432.

Pusat Data dan Analisa Tempo. (2021). Berharap Lonjakan Omzet di Masa Pandemi. In PENGUSAHA RETAIL MENYIASATI BISNIS DI ERA PANDEMI (p. 12).

Thabit, F., Alhomdy, A. P. S., Al-Ahdal, A. H. A., \& Jagtap, P. D. S. (2020). Jurnal Comasie. Global Transitions Proceedings, 3(3), 21-30.

Tusarwenda, T. R. I. B. (2018). Penerapan data mining dengan algoritma c4.5 dalam prediksi penjualan botol pada cv. seribukilo. 


\section{PROFIL PENULIS}

\section{Meliana Leonardi}

Tahun 2020 lulus dari Program Ahli Madya (A,Md.) Program Studi Sistem Informasi Universitas Bina Sarana Informatika dan sekarang sedang melanjutkan Program Strata Satu (S1) Universitas Nusa Mandiri.

\section{Riska Emilda}

Tahun 2020 lulus dari Program Ahli Madya (A,Md.) Program Studi Sistem Informasi Universitas Bina Sarana Informatika dan sekarang sedang melanjutkan Program Strata Satu (S1) Universitas Nusa Mandiri.

\section{Irena Katrin}

Tahun 2020 lulus dari Program Ahli Madya (A,Md.) Program Studi Sistem Informasi Universitas Bina Sarana Informatika dan sekarang sedang melanjutkan Program Strata Satu (S1) Universitas Nusa Mandiri. 